\title{
Effects of Deicers on Concrete Deterioration
}

\author{
by David Darwin, JoAnn Browning, Lien Gong, and Sean R. Hughes
}

Concrete specimens were exposed to weekly cycles of wetting and drying in distilled water and in solutions of sodium chloride ( $\mathrm{NaCl})$, calcium chloride $\left(\mathrm{CaCl}_{2}\right)$, magnesium chloride $\left(\mathrm{MgCl}_{2}\right)$, and calcium magnesium acetate (CMA) with either a 6.04 molal ion concentration, equivalent in ion concentration to a $15 \%$ solution of $\mathrm{NaCl}$, or a 1.06 molal ion concentration, equivalent in ion concentration to a $3 \%$ solution of $\mathrm{NaCl}$, for periods of up to 95 weeks. Specimens were also exposed to air only. The effects of exposure were evaluated based on changes in the dynamic modulus of elasticity and the physical appearance of the specimens at the conclusion of the tests.

Concretes exposed to distilled water and air show, respectively, an increase and a decrease in dynamic modulus of elasticity, due principally to changes in moisture content; overall, no negative impact on the properties of these specimens is observed. At lower concentrations, $\mathrm{NaCl}$ and $\mathrm{CaCl}_{2}$ have a relatively small negative impact on the properties of concrete. At high concentrations, $\mathrm{NaCl}$ has a greater but still relatively small negative effect. At low concentrations, $\mathrm{MgCl}_{2}$ and CMA can cause measurable damage to concrete. At high concentrations, $\mathrm{CaCl}_{2}, \mathrm{MgCl}_{2}$, and $\mathrm{CMA}$ cause significant changes in concrete that result in loss of material and a reduction in stiffness and strength.

Keywords: calcium chloride; calcium magnesium acetate; chlorides; concrete; deicing salts; magnesium chloride; sodium chloride.

\section{INTRODUCTION}

The application of deicing chemicals can result in the deterioration of concrete roads and bridges by causing scaling when the concrete is subjected to cycles of freezing and thawing. Deicing chemicals can also cause concrete to deteriorate as the result of salt crystallization within the pores of both cement paste and aggregate and chemical changes to occur within the cement paste, whether or not the deicers cause significant scaling damage. Studies have demonstrated that sodium chloride $(\mathrm{NaCl})$ and calcium chloride $\left(\mathrm{CaCl}_{2}\right)$, the two principle deicing chemicals, cause maximum scaling under freezing-and-thawing conditions at concentrations in water between 2 and $4 \%$ by weight, with $\mathrm{NaCl}$ having the greater effect. ${ }^{1,2}$ Concentrations outside of this range, both lower and higher, have less effect on scaling. In contrast, studies of concrete deterioration caused by cycles of wetting and drying show that deterioration increases with an increasing concentration of the solution. ${ }^{3}$ The latter observation has important implications because high concentration solutions are often used for deicing and because deicer concentrations will build up in concrete over time.

One drawback in studies of the effects of wetting and drying with deicers is that comparisons are typically made using solutions that have either an equal weight of deicing chemical or an equal molar concentration (equal number of molecules for a given volume of solution). ${ }^{3,4}$ The problem with this approach is that the ice melting capability of a deicer, and thus the concentration at which it is used, is more closely related to the number of ions in a given quantity of water than to either the weight or molar concentration. Thus, at the same molar concentration, $\mathrm{CaCl}_{2}$ will have $50 \%$ more ions in solution than $\mathrm{NaCl}$. The test procedures used in this study account for the number of ions produced when a deicer goes into solution, providing a fairer measure than the other approaches in evaluating the effects of deicers on concrete.

A number of different test procedures have been used to evaluate the effects of wetting and drying. These have included cycles at room temperature, cycles at elevated temperatures, as high as $58^{\circ} \mathrm{C}\left(135^{\circ} \mathrm{F}\right)$, and wetting and drying cycles that include changes in temperature during both the wet and dry cycles. Specimens are usually evaluated based on physical changes at the macroscopic and microscopic level, as well as chemical changes that are observed using petrographic analysis, scanning electron microscopy, and X-ray microanalysis.

Previous studies indicate that deicers can affect the chemistry of hardened cement paste. ${ }^{3-6}$ Chloride solutions tend to cause the formation of calcium chloride hydrate and calcium oxychloride, whereas magnesium chloride $\left(\mathrm{MgCl}_{2}\right)$, in particular, results in the conversion of calcium silicate hydrate to noncementitious magnesium silicate hydrate. In mixtures of calcium and magnesium acetate (CMA), a deicer that does not cause corrosion of reinforcing steel, magnesium acetate has been shown to cause the most severe damage, due to the formation of magnesium silicate hydrate, with little negative effect demonstrated by calcium acetate. ${ }^{4}$ To the extent that crystal growth plays a role in deterioration, $\mathrm{CaCl}_{2}$, $\mathrm{MgCl}_{2}$, and calcium acetate, but not magnesium acetate or $\mathrm{NaCl}$, are hygroscopic, forming lower density (and thus high volume) crystals when moisture is available. ${ }^{7}$ The greater volume of the hydrated salt crystals can increase the crystal pressure, with a simultaneous increase in the potential for physical damage. ${ }^{8}$

The effects of CMA on concrete have been observed in ongoing corrosion research at the University of Kansas, with molal ion concentrations (based on the number of ions for a given quantity of water) equivalent to a $15 \% \mathrm{NaCl}$ solution causing severe damage, not only to the concrete in corrosion specimens but also to the adjacent concrete floor. CMA solutions with molal ion concentrations equivalent to a $3 \% \mathrm{NaCl}$ solution have resulted in much less damage.

This paper describes the results of a study in which the effects of four deicers- $\mathrm{NaCl}, \mathrm{CaCl}_{2}, \mathrm{MgCl}_{2}$, and $\mathrm{CMA}-$ on concrete are compared by combining exposure procedures that were originally developed to allow deicing chemicals to rapidly penetrate concrete corrosion specimens with techniques that are used to evaluate the physical effects of cyclic

ACI Materials Journal, V. 105, No. 6, November-December 2008.

MS No. M-2008-018 received Janurary 16, 2008, and reviewed under Institute publication policies. Copyright (C) 2008, American Concrete Institute. All rights reserved, including the making of copies unless permission is obtained from the copyright proprietors. Pertinent discussion including authors' closure if any, will be published in the September-October 2009 ACI Materials Journal if the discussion is received by June 1, 2009. 
ACI Past President David Darwin, FACI, is the Deane E. Ackers Distinguished Professor of Civil, Environmental and Architectural Engineering and Director of the Structural Engineering and Materials Laboratory at the University of Kansas, Lawrence, KS. He is a member of ACI Committee; 130, Sustainability of Concrete; 222, Corrosion of Metals in Concrete; 224, Cracking; 318-B, Reinforcement and Development (Structural Concrete Building Code); 408, Bond and Development of Reinforcement; 446, Fracture Mechanics; and Joint ACI-ASCE Committee 445, Shear and Torsion.

ACI member JoAnn Browning is an Associate Professor of civil, environmental, and architectural engineering at the University of Kansas. She is Chair of Committee 314, Simplified Design of Concrete Buildings, and is a member of 318-D. Flexure and Axial Loads: Beams, Slabs, and Columns; 341, Earthquake-Resistant Concrete Bridges; 374, Performance-Based Seismic Design of Concrete Buildings; and 408, Bond and Development of Reinforcement.

Lien Gong is a Civil Engineer with Black and Veatch Consulting Engineers. She received her $B S$ in architectural engineering from Chongqing University, Chongqing, China, and her MS and PhD in civil engineering from the University of Kansas.

Sean R. Hughes is a Lieutenant Junior Grade in the U.S. Navy Civil Engineer Corps. $H$ received his $B S$ in mathematics from Baker University, Baldwin City, KS, and a BS and $M S$ in civil engineering from the University of Kansas.

freezing and thawing on concrete. The full details of the study are presented in Reference 9.

\section{RESEARCH SIGNIFICANCE}

The negative impact of deicing chemicals on the deterioration of pavements and bridges has been of concern for a number of years, especially as deicers with potentially less impact on the corrosion of reinforcing steel or greater ice-melting capacity than $\mathrm{NaCl}$ have entered the marketplace. This study compares four of the most widely used deicing chemicals and describes the first application of a widely used nondestructive evaluation technique to this problem. The results provide clear evidence that, over time, three of the deicers in the study- $\mathrm{CaCl}_{2}, \mathrm{MgCl}_{2}$, and $\mathrm{CMA}$ - have the potential to significantly weaken concrete.

\section{Materials}

\section{EXPERIMENTAL STUDY}

In the study, the effects on concrete of cyclic wetting and drying with solutions containing $\mathrm{NaCl}, \mathrm{CaCl}_{2}, \mathrm{MgCl}_{2}$, and CMA (4:6 molar ratio of calcium acetate to magnesium acetate) were evaluated. The study also includes control specimens that were exposed to air or to distilled water throughout the test period. Two concentrations were tested for each deicing chemical, a 6.04 molal ion concentration, equivalent in ion concentration to a $15 \%$ solution of $\mathrm{NaCl}$, and a 1.06 molal ion concentration, equivalent to a $3 \%$ solution of $\mathrm{NaCl}$. The compositions of the solutions are shown in Table 1.

The concrete mixture used in the study contained Type I/II portland cement and had a water-cement ratio $(w / c)$ of 0.45 and an air content of $6 \%$. Mixture proportions and aggregate properties are shown in Table 2.

Prismatic test specimens ( $3 \times 3 \times 12$ in. [76 x 76 × $305 \mathrm{~mm}$ ]) were used. The concrete was mixed and the specimens fabricated in accordance with ASTM C192. ${ }^{10}$ After casting, the specimens were covered with plastic, cured for 24 hours at room temperature, and then removed from the molds and cured in lime-saturated water at $73 \pm 3{ }^{\circ} \mathrm{F}\left(23 \pm 1.7^{\circ} \mathrm{C}\right)$ for 6 days. After 6 days, the specimens were removed from the curing tank and allowed to dry at a temperature of $73 \pm 3^{\circ} \mathrm{F}$ $\left(23 \pm 1.7^{\circ} \mathrm{C}\right)$ and a relative humidity of $50 \% \pm 4 \%$ for 48 days.

The control specimens were cast separately from those exposed to deicers. To limit variations in performance that might occur due to differences in concrete properties, the specimens exposed to the deicers were cast together, with equal numbers of specimens from each batch exposed to one of the four deicers.

\section{Test procedure}

The test procedure involves wet/dry exposure similar to that used for Southern Exposure corrosion test specimens, ${ }^{11-13}$ while the effect of the cycles is evaluated by measuring changes in the dynamic modulus of elasticity in accordance to the ASTM C215, ${ }^{14}$ as used for freeze-thaw specimens in ASTM C666. ${ }^{15}$

Six specimens were used for each of the solutions shown in Table 1, along with six specimens each in air and distilled water. The specimens were submerged in the solutions (or distilled water) for 4 days at a temperature of $73 \pm 4{ }^{\circ} \mathrm{F}(23 \pm$ $2{ }^{\circ} \mathrm{C}$ ). After 4 days, they were removed from the solution and dried in air at a temperature of $100 \pm 3{ }^{\circ} \mathrm{F}\left(38 \pm 1.7^{\circ} \mathrm{C}\right)$ for 3 days. The deicer solutions and distilled water were replaced every 5 weeks. Specimens exposed to air were subjected to the temperature cycles. Cycles were repeated for up to a maximum of 95 weeks. Based on chloride concentrations obtained at a depth of 1 in. $(25 \mathrm{~mm})$ in the corrosion specimens ${ }^{13,16}$ and on bridge decks, ${ }^{17}$ exposure to cyclic wetting and drying using this regimen simulates 10 years of exposure for bridge decks within the first 30 weeks and 30 years within the 95 -week maximum duration of the test.

The fundamental transverse resonance frequency of each specimen was measured and the dynamic modulus of elasticity (Dynamic $E$ ) calculated based on the fundamental frequency, mass, and dimensions of the specimen at the initiation of the tests and every 5 weeks thereafter (after the 3-day drying period) using the procedures described in ASTM C215. ${ }^{14}$ Changes in concrete properties were evaluated based on the ratio of the Dynamic $E$ at the given number of cycles to the Dynamic $E$ at the initiation of the wet/dry cycles. This ratio is referred to as the relative dynamic modulus of elasticity (wet-dry), or $P_{w / d}$, to distinguish it from the value of $P$ obtained

Table 1-Deicer solutions

\begin{tabular}{|c|c|}
\hline \multicolumn{2}{|r|}{ 6.04 molal ion concentration solutions } \\
\hline $\mathrm{NaCl}$ & 850 g water, ${ }^{*} 150 \mathrm{~g} \mathrm{NaCl}$ (100\% solids) \\
\hline $\mathrm{MgCl}_{2}$ & $612.5 \mathrm{~g}$ water, $579.2 \mathrm{~g} \mathrm{MgCl}_{2}(33.1 \%$ solution $)$ \\
\hline $\mathrm{CaCl}_{2}$ & $1000 \mathrm{~g}$ water, $223.5 \mathrm{~g} \mathrm{CaCl}_{2}(92.36 \%$ solids $)$ \\
\hline CMA & $1000 \mathrm{~g}$ water, $309.3 \mathrm{~g}$ CMA (96\% solids) \\
\hline \multicolumn{2}{|r|}{1.06 molal ion concentration solutions } \\
\hline $\mathrm{NaCl}$ & $970 \mathrm{~g}$ water, $30 \mathrm{~g} \mathrm{NaCl}$ (100\% solids) \\
\hline $\mathrm{MgCl}_{2}$ & $932.1 \mathrm{~g}$ water, $101.5 \mathrm{~g} \mathrm{MgCl}_{2}(33.1 \%$ solution $)$ \\
\hline $\mathrm{CaCl}_{2}$ & $1000 \mathrm{~g}$ water, $42.4 \mathrm{~g} \mathrm{CaCl}_{2}$ (92.36\% solids) \\
\hline CMA & $1000 \mathrm{~g}$ water, $54 \mathrm{~g} \mathrm{CMA} \mathrm{(96 \%} \mathrm{solids)}$ \\
\hline
\end{tabular}

*Distilled water used for all solutions.

Table 2-Concrete mixture proportions (SSD basis)

\begin{tabular}{|c|c|c|c|c|}
\hline $\begin{array}{c}\text { Cement, } \\
\mathrm{lb} / \mathrm{yd}^{3}\left(\mathrm{~kg} / \mathrm{m}^{3}\right)\end{array}$ & $\begin{array}{c}\text { Water, } \\
\mathrm{lb} / \mathrm{yd}^{3}\left(\mathrm{~kg} / \mathrm{m}^{3}\right)\end{array}$ & $\begin{array}{c}\text { Fine } \\
\text { aggregate, } \\
\mathrm{lb} / \mathrm{yd}^{3}\left(\mathrm{~kg} / \mathrm{m}^{3}\right)\end{array}$ & $\begin{array}{c}\text { Coarse } \\
\text { aggregate, } \\
\mathrm{lb} / \mathrm{yd}^{3}\left(\mathrm{~kg} / \mathrm{m}^{3}\right)\end{array}$ & $\begin{array}{c}\text { Vinsol resin, } \\
\text { gal./yd }\left(\mathrm{mL}^{3} / \mathrm{m}^{3}\right)\end{array}$ \\
\hline $598(355)$ & $270(160)$ & $1436(852)$ & $1473(874)$ & $0.024(90)$ \\
\hline
\end{tabular}

Notes: Concrete properties: $w / c=0.45,6 \pm 1 \%$ entrained air, and $3 \pm 0.5$ in. $(76 \pm 13 \mathrm{~mm})$ slump; cement: Type I/II portland cement; fine aggregate: sand with bulk specific gravity (SSD) of 2.62 , absorption of $0.78 \%$, and fineness modulus of 2.51 ; and coarse aggregate: (SSD) of 2.62 , absorption of $0.78 \%$, and fineness modulus of 2.51 ; and coarse aggregate:
crushed limestone $3 / 4$ in. $(19 \mathrm{~mm})$ nominal maximum size, bulk specific gravity (SSD) of 2.58 , absorption of $2.27 \%$, and unit weight of $95.9 \mathrm{lb} / \mathrm{ft}^{3}\left(1536 \mathrm{~kg} / \mathrm{m}^{3}\right)$. 
using ASTM C666 for specimens subjected to cycles of freezing and thawing. Wet/dry cycles continued for a total of 95 weeks or until $P_{w / d}$ drops below 0.9 , at which point the tests were terminated. This value for $P_{w / d}$ was used to terminate the tests because it signals very rapid deterioration of the specimens.

\section{TEST RESULTS}

The average values and coefficients of variation (COV) of the dynamic moduli of elasticity (for six specimens of each type) at 5-week intervals are presented in Tables 3, 4, and 5, covering, respectively, specimens subjected to cycles in air and distilled water, cycles in the 6.04 molal ion concentration deicer solutions, and cycles in the 1.06 molal ion concentration deicer solutions. The initial (zero-cycle) average Dynamic $E$

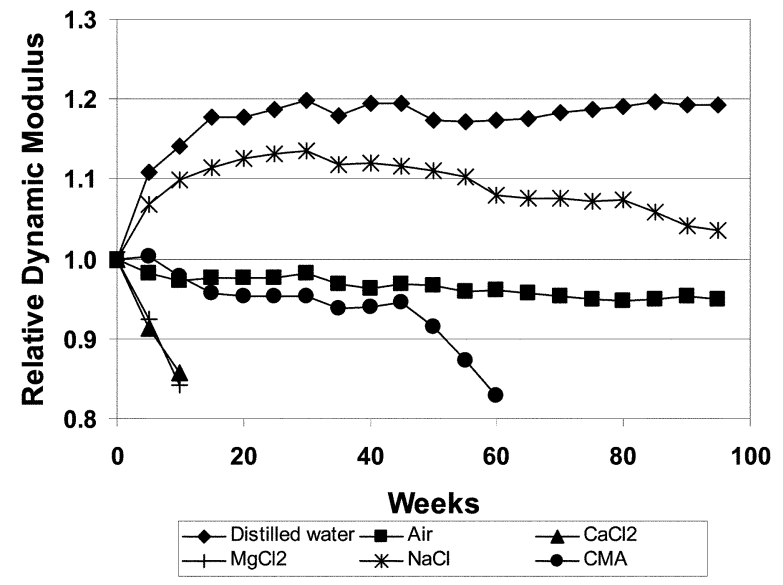

Fig. 1-Relative dynamic modulus of elasticity (wet-dry) $\mathrm{P}_{\mathrm{w} / \mathrm{d}}$ versus number of weekly wet-dry cycles for specimens exposed to 6.04 molal ion concentration deicer solutions.

Table 3-Average Dynamic E (ksi) and coefficients of variation for specimens in air and distilled water

\begin{tabular}{c|c|c|c|c}
\hline & \multicolumn{2}{|c|}{ Air } & \multicolumn{2}{c}{ Distilled water } \\
\hline Time, weeks & Average & COV & Average & COV \\
\hline 0 & 4247 & 0.031 & 4549 & 0.031 \\
\hline 5 & 4173 & 0.029 & 5045 & 0.022 \\
\hline 10 & 4132 & 0.028 & 5194 & 0.022 \\
\hline 15 & 4144 & 0.028 & 5357 & 0.019 \\
\hline 20 & 4143 & 0.030 & 5357 & 0.021 \\
\hline 25 & 4148 & 0.026 & 5398 & 0.024 \\
\hline 30 & 4173 & 0.032 & 5452 & 0.019 \\
\hline 35 & 4116 & 0.039 & 5363 & 0.026 \\
\hline 40 & 4093 & 0.040 & 5431 & 0.023 \\
\hline 45 & 4111 & 0.039 & 5433 & 0.023 \\
\hline 50 & 4105 & 0.043 & 5334 & 0.023 \\
\hline 55 & 4077 & 0.042 & 5327 & 0.018 \\
\hline 60 & 4081 & 0.035 & 5336 & 0.023 \\
\hline 65 & 4067 & 0.034 & 5345 & 0.021 \\
\hline 70 & 4052 & 0.034 & 5378 & 0.023 \\
\hline 75 & 4032 & 0.031 & 5400 & 0.023 \\
\hline 80 & 4021 & 0.031 & 5418 & 0.023 \\
\hline 85 & 4033 & 0.036 & 5440 & 0.024 \\
\hline 90 & 4047 & 0.037 & 5422 & 0.026 \\
\hline 95 & 4033 & 0.032 & 5424 & 0.025 \\
\hline Note: 1000 ssi $6.895 \mathrm{GP}$ & & &
\end{tabular}

Note: $1000 \mathrm{ksi}=6.895 \mathrm{GPa}$. value at zero cycles is lowest for the specimens cycled in air (4247 ksi [29.3 GPa]), followed by the value for specimens cycled in distilled water (4549 ksi [31.4 GPa]), which, as described previously, were cast in batches separate from those cycled in deicer solutions. The initial moduli for the specimens subjected to the 6.04 and 1.06 molal ion concentration solutions average approximately 4900 and $5000 \mathrm{ksi}(33.8$ and $34.5 \mathrm{GPa}$ ), respectively. The average values at 5 -week intervals were used to calculate $P_{w / d}$. The consistency of the testing procedure is supported by the low COV, which are generally at or below $4 \%$, except for specimens undergoing significant damage. The latter specimens exhibit COV between 7.5 and $10 \%$ for values of $P_{w / d}$ below 0.9. The average relative dynamic modulus of elasticity (wet-dry) $P_{w / d}$ are presented in Fig. 1 and 2, which show the values for specimens exposed to the 6.04 and 1.06 molal ion concentration deicer solutions, respectively. The figures also include the results for the specimens subjected to wet/dry temperature cycles in distilled water and temperature cycles in air.

\section{Control specimens}

$P_{w / d}$ for the specimens subjected to wet/dry cycles with distilled water increased from 1.0 at the beginning of the test to approximately 1.1 at week 5 , increased again to 1.2 at week 35 , and then remained approximately constant through week 95 . The increase in the Dynamic $E$ may be attributed in part to an increase in the degree of hydration, but most likely resulted from the absorption of water. The specimens subjected to the temperature variations, but otherwise stored in air, exhibited a small but consistent drop in the Dynamic $E$ throughout the test due to the loss in water (with accompanying microcracking), reaching a $P_{w / d}$ of 0.95 at 95 weeks.

Table 4-Average Dynamic $E$ (ksi) and coefficients of variation for specimens in 6.04 molal ion concentration solutions of deicers

\begin{tabular}{c|c|c|c|c|c|c|c|c}
\hline \multirow{2}{*}{$\begin{array}{c}\text { Time, } \\
\text { weeks }\end{array}$} & \multicolumn{2}{|c|}{$\mathrm{NaCl}$} & \multicolumn{2}{c|}{$\mathrm{CaCl}_{2}$} & \multicolumn{2}{c|}{$\mathrm{MgCl}_{2}$} & \multicolumn{2}{c}{ CMA } \\
\cline { 2 - 9 } & Average & COV & Average & COV & Average & COV & Average & COV \\
\hline 0 & 4867 & 0.044 & 4879 & 0.053 & 4978 & 0.042 & 4881 & 0.036 \\
\hline 5 & 5197 & 0.055 & 4454 & 0.043 & 4605 & 0.030 & 4894 & 0.026 \\
\hline 10 & 5347 & 0.041 & 4180 & 0.085 & 4191 & 0.085 & 4779 & 0.031 \\
\hline 15 & 5424 & 0.046 & - & - & - & - & 4675 & 0.020 \\
\hline 20 & 5481 & 0.031 & - & - & - & - & 4653 & 0.030 \\
\hline 25 & 5502 & 0.037 & - & - & - & - & 4651 & 0.019 \\
\hline 30 & 5526 & 0.025 & - & - & - & - & 4656 & 0.030 \\
\hline 35 & 5445 & 0.033 & - & - & - & - & 4578 & 0.027 \\
\hline 40 & 5451 & 0.033 & - & - & - & - & 4587 & 0.040 \\
\hline 45 & 5436 & 0.029 & - & - & - & - & 4620 & 0.046 \\
\hline 50 & 5406 & 0.028 & - & - & - & - & 4464 & 0.051 \\
\hline 55 & 5371 & 0.036 & - & - & - & - & 4258 & 0.051 \\
\hline 60 & 5256 & 0.048 & - & - & - & - & 4045 & 0.050 \\
\hline 65 & 5232 & 0.039 & - & - & - & - & - & - \\
\hline 70 & 5240 & 0.041 & - & - & - & - & - & - \\
\hline 75 & 5221 & 0.037 & - & - & - & - & - & - \\
\hline 80 & 5225 & 0.035 & - & - & - & - & - & - \\
\hline 85 & 5152 & 0.049 & - & - & - & - & - & - \\
\hline 90 & 5071 & 0.046 & - & - & - & - & - & - \\
\hline 95 & 5040 & 0.041 & - & - & - & - & - & - \\
\hline Note: $1000 \mathrm{ksi}=6.895 \mathrm{GPa}$ & & & & & &
\end{tabular}




\section{High concentration of deicers}

As shown in Fig. 1, the specimens exposed to the 6.04 molal ion concentrations of $\mathrm{CaCl}_{2}$ and $\mathrm{MgCl}_{2}$ deteriorated rapidly, with $P_{w / d}$ dropping below 0.9 by week 10 . The specimens exposed to CMA deteriorated more slowly, with $P_{w / d}$ dropping below 0.9 by week 55 ; the wet/dry cycles for these specimens were continued for another 5 weeks. The concrete subjected to the 6.04 molal ion concentration $\mathrm{NaCl}$ solution exhibited a rise in $P_{w / d}$ through week 30 to 1.14 , likely due to the absorption of water and perhaps the formation of salt crystals, which filled some of the pore space within the cement paste, followed by a gradual drop to a value of 1.04 at week 95 , indicating damage, also likely due to salt crystal formation (refer to the Visual evaluation section).

\section{Low concentration of deicers}

As shown in Fig. 2, the use of lower concentrations of deicers reduced the negative effects of all four deicers compared with that observed at the high concentration, in some cases significantly. During the early weeks of the tests, all specimens submerged in the 1.06 molal ion concentration deicer solutions exhibited an increase in $P_{w / d}$, as described for the specimens exposed to distilled water. The specimens exposed to $\mathrm{CaCl}_{2}$ and $\mathrm{NaCl}$ exhibited the greatest increase, with peak values of $P_{w / d}$ of 1.11 . After week $45, P_{w / d}$ for these specimens began to drop very slowly, indicating some damage, reaching a value of 1.07 at week 95 . This value (1.07) is higher than that observed for the higher concentration solutions $\left(0.86\right.$ at week 10 for $\mathrm{CaCl}_{2}$ and 1.04 at week 95 for $\mathrm{NaCl}$ ). The peak value of $P_{w / d}$ for the high concentration $\mathrm{NaCl}$ specimens (1.14) was slightly higher than the value observed at the lower concentration (1.11). The difference may be due to the effects of increased crystallization

Table 5-Average Dynamic $E$ (ksi) and coefficients of variation for specimens in 1.06 molal ion concentration solutions of deicers

\begin{tabular}{c|c|c|c|c|c|c|c|c}
\hline \multirow{2}{*}{$\begin{array}{c}\text { Time, } \\
\text { weeks }\end{array}$} & \multicolumn{2}{|c|}{$\mathrm{NaCl}$} & \multicolumn{2}{c|}{$\mathrm{CaCl}_{2}$} & \multicolumn{2}{c|}{$\mathrm{MgCl}_{2}$} & \multicolumn{2}{c}{ CMA } \\
\cline { 2 - 9 } & Average & COV & Average & COV & Average & COV & Average & COV \\
\hline 0 & 5005 & 0.013 & 5072 & 0.022 & 5050 & 0.012 & 5085 & 0.048 \\
\hline 5 & 5160 & 0.020 & 5334 & 0.023 & 5322 & 0.018 & 5302 & 0.045 \\
\hline 10 & 5399 & 0.016 & 5553 & 0.011 & 5486 & 0.015 & 5346 & 0.051 \\
\hline 15 & 5389 & 0.015 & 5568 & 0.019 & 5426 & 0.004 & 5342 & 0.049 \\
\hline 20 & 5486 & 0.017 & 5630 & 0.013 & 5469 & 0.013 & 5399 & 0.050 \\
\hline 25 & 5513 & 0.023 & 5632 & 0.005 & 5374 & 0.024 & 5388 & 0.049 \\
\hline 30 & 5544 & 0.016 & 5667 & 0.013 & 5487 & 0.010 & 5413 & 0.042 \\
\hline 35 & 5483 & 0.013 & 5543 & 0.023 & 5355 & 0.022 & 5235 & 0.055 \\
\hline 40 & 5539 & 0.016 & 5634 & 0.014 & 5348 & 0.015 & 5193 & 0.053 \\
\hline 45 & 5512 & 0.014 & 5643 & 0.018 & 5418 & 0.014 & 5295 & 0.055 \\
\hline 50 & 5286 & 0.021 & 5492 & 0.022 & 5058 & 0.031 & 4871 & 0.040 \\
\hline 55 & 5381 & 0.020 & 5543 & 0.017 & 5045 & 0.024 & 4803 & 0.043 \\
\hline 60 & 5420 & 0.021 & 5539 & 0.029 & 4889 & 0.018 & 4796 & 0.052 \\
\hline 65 & 5403 & 0.023 & 5479 & 0.020 & 4836 & 0.033 & 4779 & 0.048 \\
\hline 70 & 5390 & 0.026 & 5496 & 0.018 & 4785 & 0.049 & 4760 & 0.050 \\
\hline 75 & 5420 & 0.015 & 5493 & 0.016 & 4578 & 0.073 & 4826 & 0.057 \\
\hline 80 & 5431 & 0.018 & 5516 & 0.016 & 4371 & 0.099 & 4764 & 0.055 \\
\hline 85 & 5431 & 0.019 & 5475 & 0.019 & - & - & 4759 & 0.054 \\
\hline 90 & 5467 & 0.010 & 5475 & 0.017 & - & - & 4758 & 0.052 \\
\hline 95 & 5369 & 0.023 & 5452 & 0.022 & - & - & 4624 & 0.059 \\
\hline
\end{tabular}

Note: $1000 \mathrm{ksi}=6.895 \mathrm{GPa}$. within the pores for the specimens exposed to the higher concentration solution.

$P_{w / d}$ for specimens exposed to the 1.06 molal ion concentration $\mathrm{CMA}$ and $\mathrm{MgCl}_{2}$ solutions reached values as high as 1.07 and 1.09 , respectively, remaining nearly constant through week 45 and then dropping thereafter. $P_{w / d}$ for the CMA specimens dropped below 1.0 at week 50, reaching a value of 0.91 at week 95 . The $\mathrm{MgCl}_{2}$ specimens, which initially exhibited a slightly higher value of $P_{w / d}$ than the CMA specimens and maintained $P_{w / d}$ above 1.0 until week 55, exhibited a more rapid drop in dynamic modulus after week 70, reaching a value of $P_{w / d}$ below 0.9 by week 80 .

\section{Visual evaluation}

The specimens were evaluated for physical damage and photographs were taken at the conclusion of the tests. The appearance of the specimens is largely in agreement with the performance represented in Fig. 1 and 2.

Specimens subjected to temperature cycles in air (not shown) and wet-dry cycles in distilled water or in 1.06 molal ion concentration $\mathrm{NaCl}$ and $\mathrm{CaCl}_{2}$ solutions (Fig. 3, 4, and 5, respectively) showed few signs of damage. The only apparent change was a slight discoloration of the $\mathrm{CaCl}_{2}$

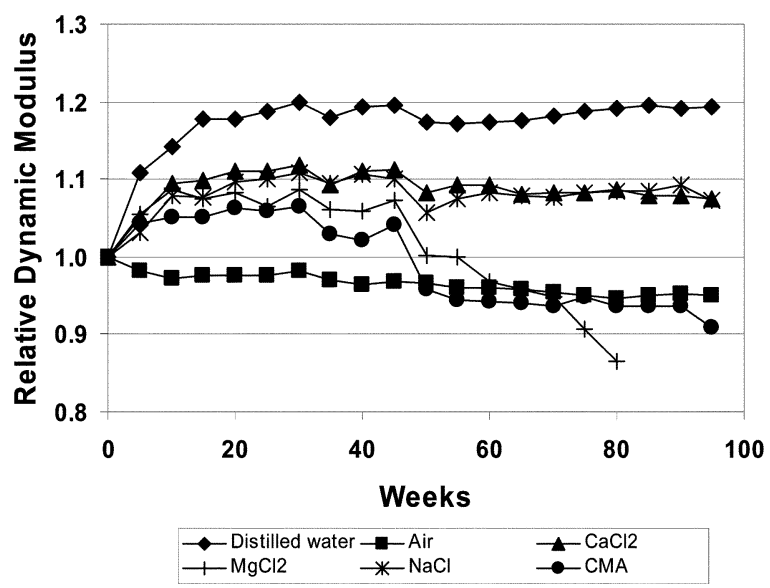

Fig. 2-Relative dynamic modulus of elasticity (wet-dry) $\mathrm{P}_{\mathrm{w} / \mathrm{d}}$ versus number of weekly wet-dry cycles for specimens exposed to 1.06 molal ion concentration deicer solutions.

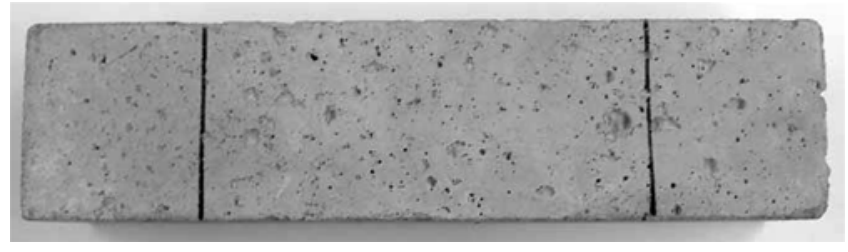

Fig. 3-Specimen subjected to 95 weeks of exposure to distilled water.

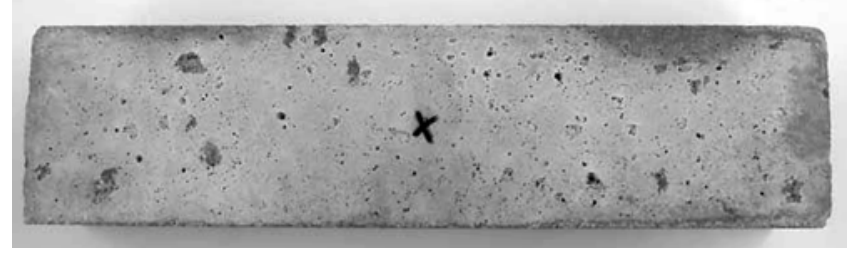

Fig. 4-Specimen subjected to 95 weeks of exposure to 1.06 molal ion concentration solution of $\mathrm{NaCl}$. 
specimens (Fig. 5). In contrast to the $\mathrm{NaCl}$ and $\mathrm{CaCl}_{2}$ specimens, the specimens subjected to $\mathrm{MgCl}_{2}$ and $\mathrm{CMA}$ exhibit signs of damage, as shown in Fig. 6 and 7, respectively. The $\mathrm{MgCl}_{2}$ specimens (Fig. 6) were subjected to wet-dry cycles for 80 weeks, after which the test was terminated because the modulus of elasticity had dropped below $90 \%$ of its initial value. The CMA specimen (Fig. 7) completed 95 weeks of wet-dry cycling.

All of the specimens subjected to the 6.04 molal ion concentration solutions exhibited damage at the conclusion of the test. Of these specimens, only the specimens in the $\mathrm{NaCl}$ solution lasted for the full 95 weeks. As shown in Fig. 8, the $\mathrm{NaCl}$ specimens exhibited some surface scaling, likely the result of crystal growth in the concrete pores. The specimens subjected to 6.04 molal ion concentrations of $\mathrm{CaCl}_{2}$ and $\mathrm{MgCl}_{2}$ (Fig. 9 and 10) exhibited the greatest degree of damage, with a loss of material from the ends and edges of the specimens, as well as some delamination. This

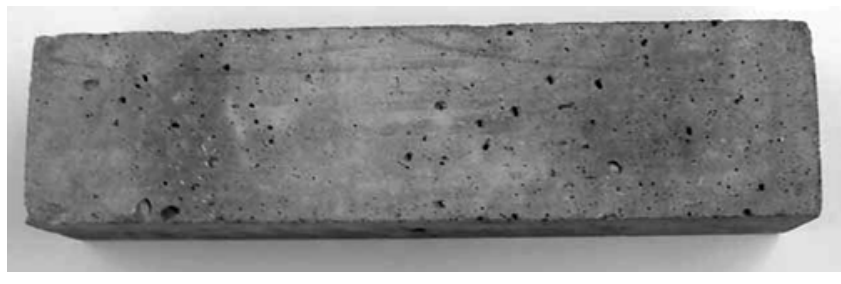

Fig. 5-Specimen subjected to 95 weeks of exposure to 1.06 molal ion concentration solution of $\mathrm{CaCl}_{2}$.

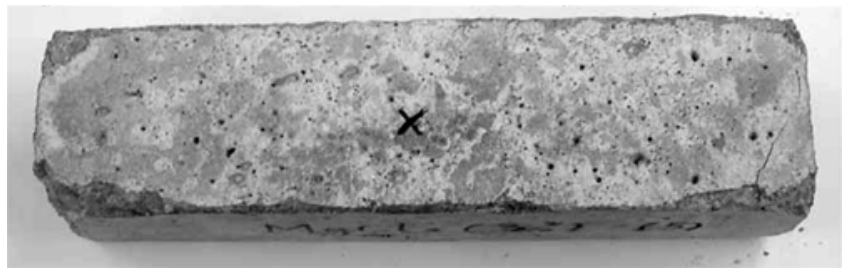

Fig. 6-Specimen subjected to 80 weeks of exposure to 1.06 molal ion concentration solution of $\mathrm{MgCl}_{2}$.

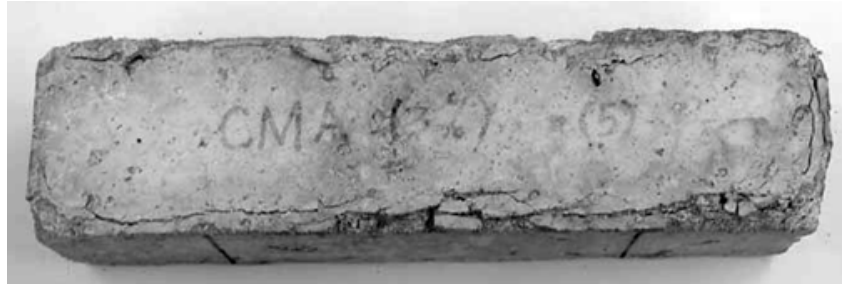

Fig. 7-Specimen subjected to 95 weeks of exposure to 1.06 molal ion concentration solution of CMA.

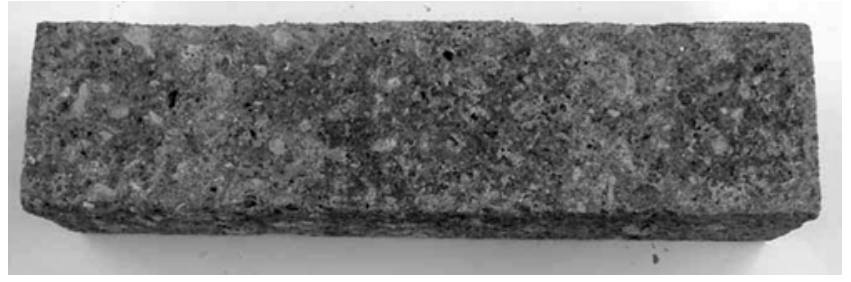

Fig. 8-Specimen subjected to 95 weeks of exposure to 6.04 molal ion concentration solution of $\mathrm{NaCl}$. high level of damage is consistent with both crystal formation in the concrete pores and chemical changes in the cement paste, as suggested in previous studies. ${ }^{3-6}$ The $\mathrm{CaCl}_{2}$ and $\mathrm{MgCl}_{2}$ specimens also exhibited the greatest reduction in modulus of elasticity, with the tests terminating at 10 weeks, as shown in Fig. 1. The specimens subjected to the 6.04 molal ion concentration CMA solution (Fig. 11) exhibited a nearly uniform loss of material on all exposed surfaces - a change that is in concert with previous observations of chemical changes in the cement paste, ${ }^{4}$ as well as some effects of crystal growth. The relative dynamic modulus of these specimens dropped below 0.9 at week 55 (Fig. 1).

Overall, the results of this study, as represented by the measured changes in modulus of elasticity and observable damage to the test specimens, indicate that $\mathrm{CaCl}_{2}, \mathrm{MgCl}_{2}$, and CMA have a negative impact on the long-term durability of concrete subjected to cyclic wetting and drying. As shown in Fig. 2, 6, and 7, the effects of $\mathrm{MgCl}_{2}$ and $\mathrm{CMA}$ should become apparent at an earlier age than the effects of $\mathrm{CaCl}_{2}$ (Fig. 5). In the longer term, all three deicers will significantly weaken concrete (Fig. 1 and 9 to 11 ). $\mathrm{NaCl}$, the most widely used deicer in U.S. practice, has a more benign impact due to the effects of cyclic wetting and drying in both the short and long term than do the other deicers in the study.

\section{SUMMARY AND CONCLUSIONS}

Concrete specimens were exposed to weekly Southern Exposure-type cycles of wetting and drying in distilled water and in solutions of $\mathrm{NaCl}, \mathrm{CaCl}_{2}, \mathrm{MgCl}_{2}$, and CMA with

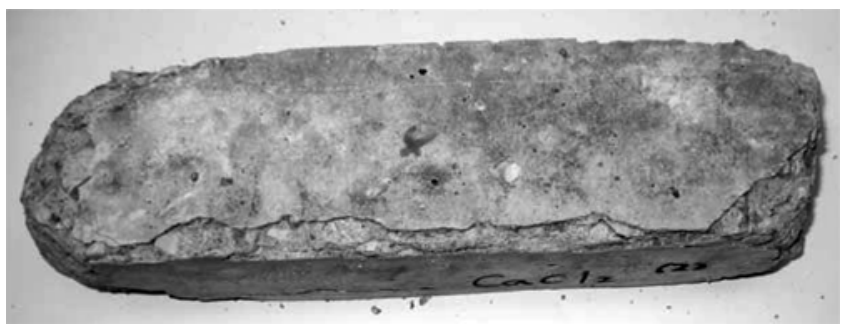

Fig. 9-Specimen subjected to 10 weeks of exposure to 6.04 molal ion concentration solution of $\mathrm{CaCl}_{2}$.

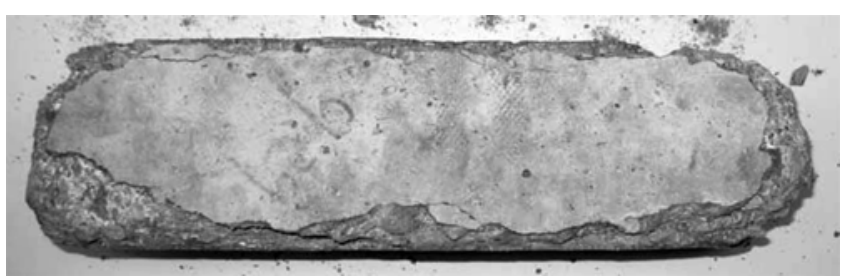

Fig. 10-Specimen subjected to 10 weeks of exposure to 6.04 molal ion concentration solution of $\mathrm{MgCl}_{2}$.

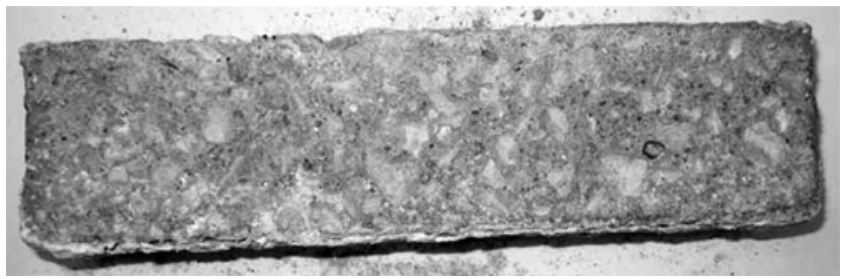

Fig. 11-Specimen subjected to 60 weeks of exposure to 6.04 molal ion concentration solution of CMA. 
either a 6.04 molal ion concentration, equivalent in ion concentration to a $15 \%$ solution of $\mathrm{NaCl}$, or a 1.06 molal ion concentration, equivalent in ion concentration to a $3 \%$ solution of $\mathrm{NaCl}$, for periods of up to 95 weeks. Specimens were also exposed to air only. The effects of exposure were evaluated based on changes in the dynamic modulus of elasticity and the physical appearance of the specimens at the conclusion of the tests.

The following conclusions are based on the test results and analyses presented in this paper.

1. Concretes exposed to distilled water and air show, respectively, an increase and a decrease in dynamic modulus of elasticity, due principally to changes in moisture content. Overall, no negative impact on concrete properties was observed;

2. At lower concentrations, $\mathrm{NaCl}$ and $\mathrm{CaCl}_{2}$ have a relatively small negative impact on the properties of concrete. At high concentrations, $\mathrm{NaCl}$ has a greater but still relatively small negative effect;

3. At low concentrations, $\mathrm{MgCl}_{2}$ and $\mathrm{CMA}$ can cause measurable damage to concrete;

4. At high concentrations, $\mathrm{CaCl}_{2}, \mathrm{MgCl}_{2}$, and CMA cause significant changes in concrete that result in loss of material and a reduction in stiffness and strength; and

5. The application of significant quantities of $\mathrm{CaCl}_{2}$, $\mathrm{MgCl}_{2}$, and CMA over the life of a structure or pavement will negatively impact the long-term durability of concrete.

\section{ACKNOWLEDGMENTS}

The research described in this paper was supported by the Structural Engineering and Materials Laboratory of the University of Kansas.

\section{REFERENCES}

1. Verbeck, G., and Klieger, P., "Studies of 'Salt' Scaling," Research Department Bulletin 83, Portland Cement Association, Chicago, IL, June 1957, 13 pp.

2. Marchand, J.; Pigeon, M.; Bager, D.; and Talbot, C., "Influence of Chloride Solution Concentration on Deicer Salt Scaling Deterioration of Concrete," ACI Materials Journal, V. 96, No. 4, July-Aug. 1999, pp. 429-435.

3. Cody, R. D.; Cody, A. M.; Spry, P. G.; and Gan, G.-L., "Concrete Deterioration by Deicing Salts: An Experimental Study," Proceedings, Semisequicentennial Transportation Conference, Iowa State University, Ames, IA, May 1996. http://www.ctre.iastate.edu/pubs/semisesq/session1/ cody/index.htm.
4. Lee, H.; Cody, A. M.; Cody, R. D.; and Spry, P. G., "Effects of Various Deicing Chemicals on Pavement Concrete Deterioration," Proceedings, Mid-Continent Transportation Symposium, Center for Transportation Research and Education, Iowa State University, Ames, IA, 2000, pp. 151-155.

5. Taylor, H. F. W., Cement Chemistry, second edition, Thomas Telford Publishing, London, UK, 1997, 459 pp.

6. Sutter, L.; Peterson, K.; Touton, S.; Van Dam; T.; and Johnston, D., "Petrographic Evidence of Calcium Oxychloride Formation in Mortars Exposed to Magnesium Chloride Solution," Cement and Concrete Research, V. 36, No. 6, Aug. 2006, pp. 1533-1541.

7. D. R. Lide, ed., Handbook of Chemistry and Physics, eighty-eighth edition, CRC Press, 2007, 2640 pp.

8. Charola, A. E., "Salts in the Deterioration of Porous Materials: An Overview," Journal of the American Institute of Conservation, JAIC online, V. 39, No. 3, Art. 2, 2000, http://aic.stanford.edu/jaic/articles/jaic39-03002_indx.html.

9. Darwin, D.; Browning, J.; Gong, L.; and Hughes, S., "Effects of Deicers on Concrete Deterioration," SL Report 07-3, University of Kansas Center for Research, Lawrence, KS, Dec. 2007, 21 pp.

10. ASTM C192/C192M-07, "Standard Practice for Making and Curing Concrete Test Specimens in the Laboratory," ASTM International, West Conshohocken, PA, 2007, 8 pp.

11. McDonald, D. B.; Pfeifer, D. W.; and Sherman, M. R., "Corrosion Evaluation of Epoxy-Coated, Metallic Clad and Solid Metallic Reinforcing Bars in Concrete," Publication Number FHWA-RD-98-153, U.S. Department of Transportation Federal Highway Administration, 1998, 127 pp.

12. Darwin, D.; Browning, J.; Nguyen, T. V.; and Locke, C. E., "Multiple Corrosion Protection Systems for Reinforced Concrete Bridge Components," Publication No. FHWA-HRT-07-043, Federal Highway Administration, July 2007, 92 pp., also SM Report No. 84, University of Kansas Center for Research, Lawrence, KS

13. Darwin, D.; Browning, J.; Nguyen, T. V.; and Locke, C. E., "Evaluation of Metallized Stainless Steel Clad Reinforcement," South Dakota Department of Transportation Report, SD2002-16-F, July 2007, 156 pp., also SM Report No. 90, University of Kansas Center for Research, Lawrence, KS.

14. ASTM C215-02, "Standard Test Method for Fundamental Transverse, Longitudinal, and Torsional Frequencies of Concrete Specimens," American Society for Testing and Materials, West Conshohocken, PA, 2002, 7 pp.

15. ASTM C666/C666M-03, "Standard Test Method for Resistance of Concrete to Rapid Freezing and Thawing," ASTM International, West Conshohocken, PA, 2003, 6 pp.

16. Ji, J.; Darwin, D.; and Browning, J., "Corrosion Resistance of Duplex Stainless Steels and MMFX Microcomposite Steel for Reinforced Concrete Bridge Decks," SM Report No. 80, University of Kansas Center for Research, Inc., Lawrence, KS, Dec. 2005, 453 pp.

17. Lindquist, W. D.; Darwin, D.; Browning, J.; and Miller, G. G., "Effect of Cracking on Chloride Content in Concrete Bridge Decks," $\mathrm{ACI}$ Materials Journal, V. 103, No. 6, Nov.-Dec. 2006, pp. 467-473. 